\title{
The first case of mild encephalopathy with a reversible splenial lesion due to Japanese encephalitis virus infection
}

\author{
B L Man, Y P FU
}

Department of Medicine and Geriatrics, Tuen Mun Hospital Hong Kong, Hong Kong

\section{Correspondence to} Dr BL Man

beli_man@yahoo.com

\section{DESCRIPTION}

A 52-year-old man, who lived close to a pig farm, presented with headache, fever and confusion for 2 days. The Glasgow Coma Scale was 9 of 15 on admission. No focal neurological sign was detected. Plain CT of the brain was unremarkable. Lumbar puncture showed cerebrospinal fluid (CSF) pleocytosis with white blood cell count $340 / \mathrm{mm}^{3}$

(a)

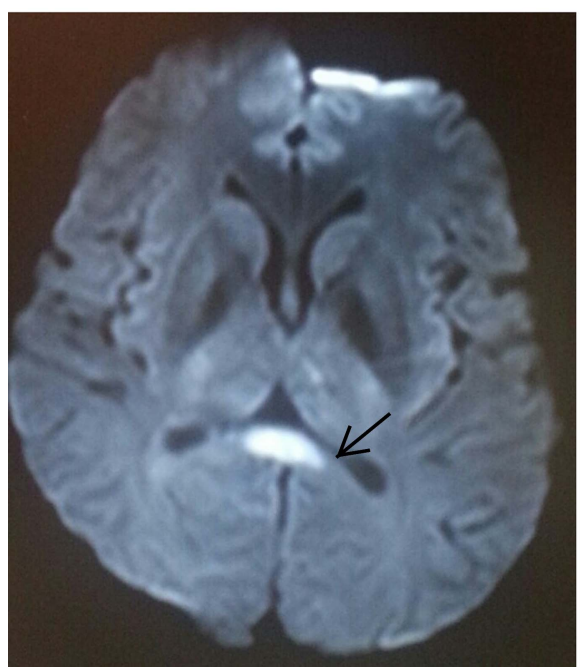

(polymorphs $72 \%$ ), protein $0.81 \mathrm{~g} / \mathrm{L} \quad(\mathrm{N}<0.45)$, glucose $4.3 \mathrm{mmol} / \mathrm{L}(\mathrm{N}>3.9)$, but negative Gram's stain and bacterial culture. Creatine phosphokinase was elevated to $7450 \mathrm{U} / \mathrm{L}(\mathrm{N}<297)$. The blood and CSF specimens were both positive for IgM to Japanese encephalitis virus. MRI diffusion-weighted imaging on admission showed a high-intensity signal with a low apparent diffusion coefficient value in the

(b)

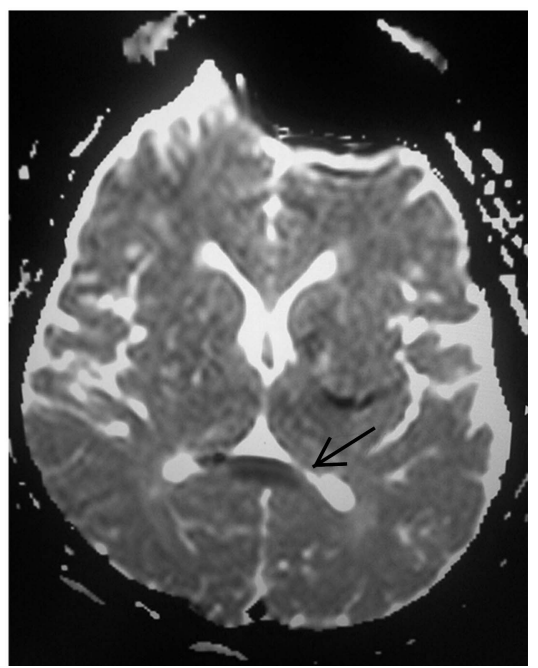

Figure 1 MRI diffusion-weighted imaging of the brain on admission. (A) MRI diffusion-weighted imaging on admission showed restricted diffusion in the splenium of the corpus callosum (arrow). (B) A low apparent diffusion coefficient $(A D C)$ value in the splenium of the corpus callosum (arrow) reflecting restricted diffusion due to cytotoxic oedema. (a)

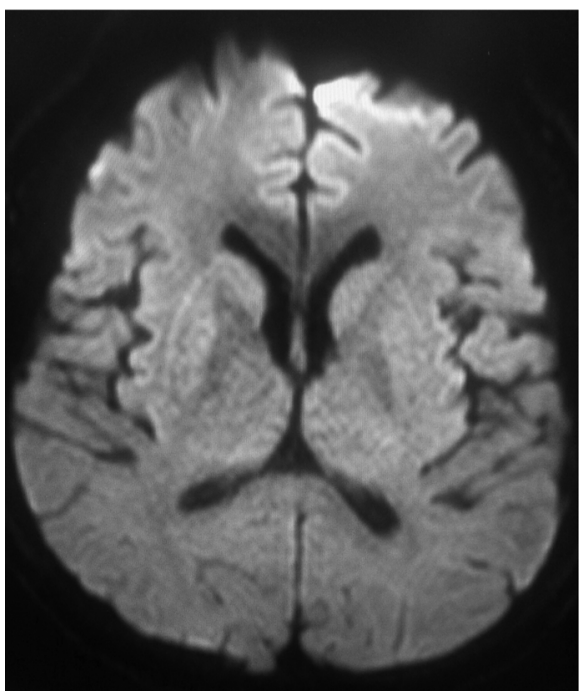

(b)

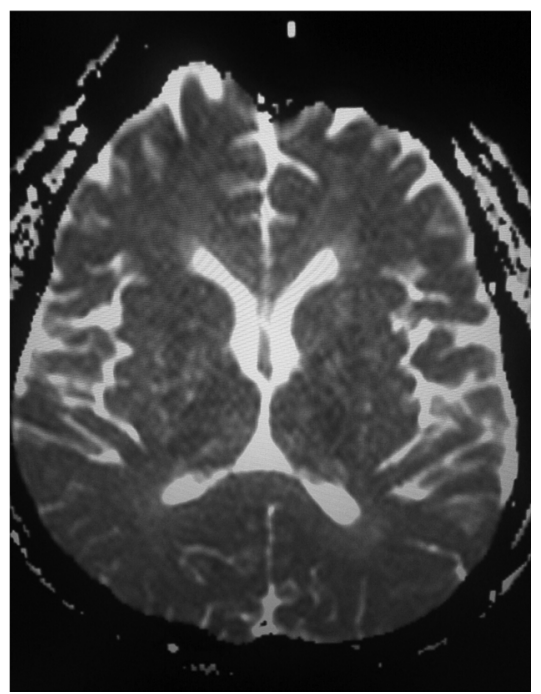

Figure 2 Follow-up MRI diffusion-weighted imaging of the brain on day 10. The abnormal signals in the splenium of the corpus callosum disappeared completely on day 10. 
splenium of the corpus callosum (figure 1, arrows), which reflected restricted diffusion due to cytotoxic oedema. This abnormal signal in the splenium resolved completely on day 10 (figure 2). His confusion recovered gradually on supportive management.

\section{Learning points}

- We report the first case of mild encephalopathy with a reversible splenial lesion due to Japanese encephalitis virus infection.

- Mild encephalopathy with a reversible splenial lesion has been described to be associated with infectious diseases, such as influenza virus, parainfluenza virus, mumps virus, adenovirus, rotavirus, Streptococcus, Escherichia coli and Salmonella enteritidis.
Mild encephalopathy with a reversible splenial lesion (MERS) has been described to be associated with infectious diseases, such as influenza virus, parainfluenza virus, mumps virus, adenovirus, rotavirus, Streptococcus, Escherichia coli and Salmonella enteritidis. ${ }^{12}$ We report the first case of MERS due to Japanese encephalitis virus infection.

Competing interests None.

Patient consent Obtained.

Provenance and peer review Not commissioned; externally peer reviewed.

\section{REFERENCES}

1 Takanashi J. Two newly proposed infectious encephalitis/encephalopathy syndromes. Brain Dev 2009;31521-8.

2 Abenhaim HL, Agyeman P, Steinlin M, et al. Mild encephalopathy with splenial lesion and parainfluenza virus infection. Pediatr Neurol 2013:48:252-4.

Copyright 2013 BMJ Publishing Group. All rights reserved. For permission to reuse any of this content visit http://group.bmj.com/group/rights-licensing/permissions.

BMJ Case Report Fellows may re-use this article for personal use and teaching without any further permission.

Become a Fellow of BMJ Case Reports today and you can:

- Submit as many cases as you like

- Enjoy fast sympathetic peer review and rapid publication of accepted articles

- Access all the published articles

- Re-use any of the published material for personal use and teaching without further permission

For information on Institutional Fellowships contact consortiasales@bmjgroup.com

Visit casereports.bmj.com for more articles like this and to become a Fellow 